\title{
Liberian Social Science Research: Third Annual Conference
}

THE third annual conference on Liberian Social Science Research is being held from 4 to 6 June $197 \mathrm{I}$ at the University of Delaware, Newark, Delaware. Participants are invited to attend four major panels, several smaller meetings, an evening illustrated lecture, and a banquet. An open invitation is being extended to scholars of Liberia to remain in Newark after the conference for whole or part of the month of June to meet other scholars working on closely allied projects and to avail themselves of library facilities specializing in Liberian materials. The conference is organized by Dr. Svend E. Holsoe, editor of the Liberian Studies Journal.

\section{Course on African Dance as Human Behaviour}

A course on African Dance as Human Behaviour was held at the Lincoln Center Campus of Fordham University, New York, from 18 to 30 January, under the direction of Professor Judith Lynne Hanna. Participants represented the disciplines of anthropology, dance, education, folklore, humanities, literature, physical education, social studies, social studies and theatre arts, and case studies of African dance in traditional contexts were combined with a broader survey of the significance of African dance as human behaviour and as artistic creation. Materials were taken from the director's own researches and films and there were five guest instructors teaching and demonstrating Zulu, Basuto, Yoruba, Amharic, and Ghanaian dances.

\section{Institute for the Study of Man in Africa}

THE VIIIth annual Raymond Dart Lecture was delivered on 16 April 1971 by Professor Jean Hiernaux, Director of the Centre of Human Biology at the Institute of Sociology, University of Brussels, on 'The Origins and Expansions of the Bantu-speaking Peoples: a New Synthesis'.

\section{Central African Art: Research Grant for Professor Daniel Biebuyck}

Professor Daniel F. Biebuyck, Professor of Anthropology and Chairman of the department at the University of Delaware, Newark, U.S.A., has received a research grant from the National Endowment for the Humanities for the preparation of a comprehensive work on Central African art. From June 1971 to the end of $197^{2}$ he will be visiting museums in a dozen European countries and examining inventories, archives, catalogues of private collections, and travel and missionary records. The work will occupy two years of research and Professor Biebuyck will spend a further year and a half preparing the materials for a three-volume publication.

\section{'African Social Research Documents'}

THE Afrika-Studiecentrum at Leiden in the Netherlands in association with the African Studies Centre of the University of Cambridge have initiated a new series entitled African Social Research Documents. The aim of the series is to provide a service for the international community in social, historical, geographical, and developmental studies by publishing documents and short monographs which would lie outside the interests of commercial publishers. The series will include special collections of documents for the series, as well as short monographs and previously unpublished reports. 